\title{
Acceptance of the Bank of Uganda Internet Banking System Framework
}

\author{
Ronald Baganzi $^{1^{*}}$ (D) Benedict Makanga ${ }^{1}$, Rebecca Isabella Kiconco² ${ }^{2}$ \\ ${ }^{1}$ Bank of Uganda, Kampala 7120, Uganda \\ ${ }^{2}$ Makerere University Business School, Kampala 1337, Uganda \\ Email: ^rbaganzi@bou.or.ug, bmakanga@bou.or.ug, rkiconco@mubs.ac.ug
}

How to cite this paper: Baganzi, R., Makanga, B., \& Kiconco, R. I. (2021). Acceptance of the Bank of Uganda Internet Banking System Framework. Open Journal of Business and Management, 9, 2894-2916. https://doi.org/10.4236/ojbm.2021.96162

Received: June 23, 2021

Accepted: November 12, 2021

Published: November 15, 2021

Copyright $\odot 2021$ by author(s) and Scientific Research Publishing Inc. This work is licensed under the Creative Commons Attribution International License (CC BY 4.0).

http://creativecommons.org/licenses/by/4.0/

(c) (i) Open Access

\begin{abstract}
The study examines the role of environmental, behavioral and technological variables in predicting customer behavioral intentions to adopt the Bank of Uganda Internet Banking System (BBS Connect) by integrating three existing frameworks of Task Technology Fit (TTF), Unified Theory of Acceptance \& Use of Technology (UTAUT) and Initial Trust Model (ITM). In doing so, the study follows a comprehensive approach to address Internet banking adoption intention. Partial Least Squares (PLS) Structural Equation Modelling is used to analyze the data collected from BBS Connect users. From the empirical findings, we are able to establish the significant contribution of technology characteristics and task characteristics in facilitating TTF. Initial trust was found to be facilitated by structural assurance and not by familiarity with the Bank of Uganda. The statistical results support the significant association of initial trust, performance expectancy and social influence with behavioral intentions to adopt BBS Connect. The approach used in the study incorporates three well established theories of technology acceptance. This results in a high explanatory power of our research model at $73.2 \%$ of behavioural intention to adopt the BBS Connect System. We provide theoretical and practical implications that are useful for Internet banking in Uganda and Africa at large.
\end{abstract}

\section{Keywords}

Internet Banking, Bank of Uganda, UTAUT, ITM, TTF, Adoption Intention

\section{Introduction}

The Bank of Uganda (BOU) plays among its other core mandates a crucial role in stabilizing the economy by providing safe and efficient online platforms for transmitting payments for goods and services. Safe and efficient payment systems are fundamental to the promotion of Financial Stability and effective 
transmission of monetary policy (Bank of Uganda, 2020). The BOU seeks to enhance financial system stability by increasing the use of e-payments (Mwesigwa, 2016). This campaign has resulted in the increased demand and usage of electronic means for discharge of claims and liabilities. In turn, the financial system has been strengthened and the implementation of the Uganda's National Financial Inclusion Strategy, 2017-2022 has been enabled (Bank of Uganda, 2019: p. 31).

At the helm of Internet banking in 2010, the BOU implemented a banking application referred to as the Bank of Uganda Banking System (BBS) which uses straight through processes (STP) for managing all banking operations (Bank of Uganda, 2017). The BBS provides an online Internet banking facility through a module known as BBS Connect that enables BOU customers access to all their banking information (Bank of Uganda, 2017). The customers who use the BBS Connect are from Government Ministries, Departments, Agencies and Projects. To enhance system security, BBS Connect users access the system using a "selfgenerated" PIN plus a token code that changes every minute (Bank of Uganda, 2018). The system uses STP which ensures that validations for accuracy are done for all transactions (Bank of Uganda, 2018). STP implies that there is no human intervention and invalid transactions are blocked and communicated instantly (Bank of Uganda, 2018). The system uses the "Maker-Checker Principle" of processing whereby the "Maker" initiates a transaction and the "Checker" authorizes it in order to achieve a complete and successful transaction life cycle (Bank of Uganda, 2018). The system is able to incorporate multiple layers of checkers to safe guard from connivance.

The Ugandan Government effects its payments largely through the Integrated Financial Management System (IFMS). However, some entities especially Projects and Local governments which are not linked to the IFMS utilize the BBS Connect (Bank of Uganda, 2019). BBS Connect offers a range of services, for instance; domestic funds transfer (RTGS), internal account transfer, own account transfer, domestic funds transfer (EFT), letters of credit, money market operations, foreign exchange, bills and collections, retail teller, bulk file upload, ability to read securely sent BOU bulletins, downloading forms, and bank accounts statement viewing and printing (Bank of Uganda, 2018).

In line with the BOU's objective of improving banking operations and providing more efficient and effective payment systems for customers, the BBS system was upgraded in March 2019 to increase STP of transactions (Bank of Uganda, 2019). The upgrade of the BBS and the BBS Connect enhancements have minimized transaction failure and the risks associated with manual processing especially, in light of the higher transaction volumes relative to previous years (Bank of Uganda, 2019). The inclusion of security enhancements on the BBS Connect has enabled faster and secure electronic forex payments to customers (Bank of Uganda, 2019). In 2020, the overall value of EFT payments rose to UGX 31.7 trillion representing an increase of $13.6 \%$ from UGX 27.91 trillion recorded 
in the previous year (Bank of Uganda, 2020). It can be argued that the increased usage of e-payments could have a positive impact on enhanced financial inclusion in Uganda.

In the financial sector, significant technological changes like mobile and Internet banking, Automated Teller Machine (ATM) have sprung up from the advancement of information technology (Roy et al., 2017: p. 418). The banking industry's landscape has been changed by Internet banking (Roy et al., 2017; Yu et al., 2015). Internet banking has transformed banking operations (Jagero \& Abeka, 2011) and the way banks offer their services and products to the customers by reducing costs of financial transactions and geographical constraints (Roy et al., 2017; Kumar et al., 2020). This has made banks highly competitive, user friendly, efficient, and able to provide customers with improved services (Roy et al., 2017; Martins et al., 2014). As a channel to market over the last 10 - 15 years, Internet banking is considered as one of the most profitable e-commerce applications and has become ubiquitous within the banking sector (Roy et al., 2017; Yadav et al., 2015).

Despite the many benefits that Internet banking offers, its adoption rate in East Africa remains low (Jagero \& Abeka, 2011). In Uganda, the proficiency of using Internet banking is still low and in its infancy stages (Yiga \& Cha, 2016). The adoption and implementation of Internet banking is still slow in banks and among customers (Musiime \& Malinga, 2011), including the government ministries and projects alike. The outbreak of Covid-19 forced the government of Uganda to impose a nationwide lockdown. Most banking customers had to embrace digital financial services like Internet banking. It is therefore crucial to understand the customers' perception towards Internet banking, so that regulatory authorities like the BOU can understand what prevents customers from adopting Internet banking. Understanding the factors that influence Internet banking acceptance will also be valuable for Ugandan banks that intend to promote the use of Internet banking among their customers. Furthermore, findings from this study can shed more light on actions to mitigate financial exclusion at a broader level.

Financial exclusion has persistently been amongst the most imminent drawbacks to growth and development in sub-Saharan Africa. With the latest technological developments and global trends, and the reasonably high level of technological adoption of low income countries, there is no doubt that Internet banking will play a significant role in the development of country financial sectors, especially low income countries, in the years to come. Uganda as a whole is no exception. We conjecture that limited empirical research exists on Internet banking adoption at a firm or government entities' level, yet it is one of the pathways to achieving financial inclusion. To the best of our knowledge, no empirical research has been conducted to ascertain the "adoption perception" of the BBS Connect users. This research is intended to examine the behavioral, environmental and technological dimensions of Internet banking acceptance by public 
entities. Results from this preliminary research will form the design of a fully-fledged Internet banking study in Uganda, incorporating not only the public sector but also the private sector as a whole. We believe that findings from this study will be relevant to the BOU in improving service delivery, technological innovation \& upgrading and robust policy implications in regards to financial technology adoption.

In the next sections, the relevant literature is discussed which includes the conceptual framework. In Section 3, we provide the research methodology. In Section 4, we provide the analysis of results. In Section 5, we provide the discussion of findings. Section 6 provides the theoretical and practical implications. These are followed by limitations and future research, and conclusions.

\section{Background}

\subsection{Conceptual Framework}

There are various theoretical models in the literature concerning information systems (IS). It stands to reason that since there is no definite theory in IS research, researchers tend to use the frameworks based on the perception and intention models from social psychology (Kumar et al., 2020; Harrison et al., 1997; Afshan \& Sharif, 2016). Internet banking particularly has been researched deeply both in academia and practice (Roy et al., 2017; Yu et al., 2015; Jagero \& Abeka, 2011; Martins et al., 2014; Afshan \& Sharif, 2016). The following theories are based on by most of these studies: the Theory of Reasoned Action (TRA) (Fishbein \& Ajzen, 1975), the Technology Acceptance Model (TAM) (Davis, 1989), the Theory of Planned Behavior (TPB) (Ajzen, 1991), and the Innovation Diffusion Theory (IDT) (Rogers, 1983). However, the most recent studies recommend an integration of various models to ascertain a holistic view to achieve research objectives (Afshan \& Sharif, 2016; Oliveira et al., 2016; Williams et al., 2009). Furthermore, none of the above models independently incorporates the different dimensions of antecedents to using technology, namely: technology based characteristics; social influences; and individual or user attributes. Therefore, based on this background it is prudent to combine various theoretical models to study adoption intentions towards new technologies (Afshan \& Sharif, 2016; Williams et al., 2009; Zhou et al., 2010; Oliveira et al., 2014). Oliveira et al. (2014) and Afshan \& Sharif (2016) recommend the integration of the Unified Theory of Acceptance and Usage of Technology (UTAUT) with the Initial Trust Model (ITM) and the Task Technology Fit (TTF) model in order to understand technology acceptance. The latter scholars argue that the combination provides an improved and better understanding of behavioral intentions. Therefore, this study explores the adoption intention of BBS Connect Internet banking system in Uganda by integrating the ITM suggested by Gefen et al. (2003), the UTAUT suggested by Venkatesh et al. (2003), and the TTF model suggested by Goodhue and Thompson (1995). To the best of our knowledge, no empirical study on Internet banking has been conducted in Uganda using this approach. This study therefore fills 
the gap in the literature by contributing a conceptual BBS Connect adoption intentions model. This will be of relevance to Internet banking in Uganda and Africa at large.

\subsubsection{Task Technology Fit (TTF) Model}

User perception based models are common amongst technology acceptance studies (Afshan \& Sharif, 2016). However, according to Goodhue (1995), the TTF model is premised on the need to find a fit between task requirements and technology characteristics. The mere focus on user technology perceptions is not sufficient enough for predicting acceptance (Afshan \& Sharif, 2016). If a technology is considered efficient enough in executing daily tasks, it is more likely to be accepted (Goodhue \& Thompson, 1995). The model focuses on the practical aspects of technology usage. Consumers can be utilitarian, implying that their technology acceptance can be determined by the extent to which technology fits their needs irrespective of their perceptions and attitudes regarding the technology (Afshan \& Sharif, 2016). Based on the theoretical foundation of the TTF model, customers do not adopt a technology if it is unfit for daily tasks and it doesn't contribute to task execution (Junglas et al., 2008).

In the Internet banking context, task characteristics can include: money transfer and remittance, ubiquitous account management, and real-time account information inquiry (Zhou et al., 2010: p. 761). On the other hand, technology characteristics refer to key aspects of Internet banking technology which include immediacy, security and ubiquity (Zhou et al., 2010). TTF represents the rational perspective of what a technology is capable of doing in ensuring job optimization (Oliveira et al., 2016). It is affected by the task nature and the technology's practicality to complete the task.

The research model further proposes an overlap between the TTF and the UTUAT models, in that task technology fit can be shaped by one's effort and performance expectancy (Venkatesh et al., 2003). If BBS Connect users in government entities perceive the BBS Connect system as requiring less effort to use, and that the system will lead to higher quality performance in terms of immediacy, ubiquity and security, then the chances are high that BBS Connect will be considered a task to fit technology. We therefore base on this background to make the following hypotheses:

H1: Task characteristics positively influence task technology fit of BBS Connect.

H2: Technology characteristics positively influence task technology fit of BBS Connect.

H3: Performance expectancy positively influences the task technology fit of BBS Connect.

H4: Effort expectancy positively influences the task technology fit of BBS Connect.

H5: Task technology fit positively affects user's intention to adopt BBS Connect. 


\subsubsection{Initial Trust Model (ITM)}

Trust is an attitude of confidence expectation in risky online transactions with optimism that consumers' vulnerabilities will not be taken advantage of (Kumar et al., 2020; Baganzi et al., 2019). Initial trust is the willingness of consumers to take risks with the objective of fulfilling needs without past experiences or meaningful information from reliable sources (Oliveira et al., 2014; Kim \& Prabhakar, 2004; McKnight \& Chervany, 2001). The ITM model has gained prominence in electronic commerce research due to the role played by initial trust in technology adoption which is an area filled with uncertainty and risks (Oliveira et al., 2014; Baganzi et al., 2019). Kim et al. (2009) established that initial trust contributes to the adoption of Internet banking, with word of mouth and structural assurances being key indicators. Lowry et al. (2008) researched about the role of initial trust in Internet shopping and found that branding and quality of online presence play a pivotal role in establishing customer trust.

The ITM model provides the basis of initial trust on contributing factors of propensity to trust, trustworthiness, situational normality and firm size (Gefen et al., 2003; Kim et al., 2009). Among the environmental and structural factors, structural assurance (Kim et al., 2009; McKnight et al., 2004; Afshan \& Sharif, 2016) and familiarity with an organization (Gefen et al., 2003; Gu et al., 2009) influence initial trust. Structural assurance refers to the availability of legal procedures, regulations and guarantees to facilitate Internet banking (Gefen et al., 2003; Baganzi et al., 2019). This draws out the importance of government policy involvement in the regulation of financial entities to promote trust among customers. Familiarity with the bank is the knowledge customers possess about the bank's technology and its relevant procedures (Gefen, 2000; Afshan \& Sharif, 2016).

Internet and mobile banking rely on an indirect relationship between concerned parties (Afshan \& Sharif, 2016: p. 373). In this situation, the knowledge based trust resulting from personal interaction is absent (McKnight et al., 2002). Therefore, based on this background, the initial trust based on consumers' perspectives will be relevant in technology acceptance (Afshan \& Sharif, 2016). Where trust exists without prior experiences, consumers are believed to lack association with service providers resulting from the uncertainty surrounding their activities in using particular technologies (Kim et al., 2009). Therefore, based on this view, the trust that results can be weakened or strengthened basing on the users' experience and so its analysis is relevant (Afshan \& Sharif, 2016). We thus make the following hypotheses:

H6: Familiarity with BOU facilitates the initial trust of BBS Connect.

H7: Structural assurance facilitates the initial trust of BBS Connect.

H8: Performance expectancy positively influences the initial trust in BBS Connect.

H9: Effort expectancy positively influences the initial trust in BBS Connect.

H10: Initial trust positively influences the user's intention to adopt BBS Con- 
nect.

\subsubsection{Unified Theory of Acceptance and Use of Technology (UTAUT)}

With the increasing complexity of behaviour research and the many limitations it faces, no single model is superior to the other (Afshan \& Sharif, 2016). This has led researchers to resort to the integration of various theories so as to reduce on their limitations. Of all IT adoption models, UTAUT has been proved to be the most comprehensive (Al-Gahtani et al., 2007; Venkatesh et al., 2012; Widayat et al., 2020). The UTAUT model was developed as a result of research constraints of technology acceptance or adoption core models. After combining and reviewing eight past models of technology acceptance, Venkatesh et al. (2003) proposed the UTAUT model. In comparison with other models like TAM, TRA and TPB, UTAUT explains behavioral intentions variance most efficiently (Min et al., 2008).

Information Technology (IT) is considered a continuously emerging field in technology acceptance research and the regulations that facilitated its progress are either system focused or belief focused (Afshan \& Sharif, 2016). The UTAUT combined both system and belief focused indicators to argue that technology influence is based on four core dynamics, which include effort expectancy, performance expectancy, facilitating conditions and social influence (Venkatesh et al., 2003). Performance expectancy is the degree to which customers believe that using the BBS Connect Internet banking system will support job performance (Venkatesh et al., 2003). The degree of ease of use associated with the BBS Connect Internet Banking system is referred to as Effort expectancy (Venkatesh et al., 2003; Widayat et al., 2020). The extent to which BOU customers perceive that their important others should use the BBS Connect Internet Banking system is referred to as Social influence (Venkatesh et al., 2003). Facilitating conditions refers to the degree to which BOU customers believe that technical and organizational infrastructures are in place to support the BBS Connect Internet banking system use (Venkatesh et al., 2003; Widayat et al., 2020).

A couple of studies have used the UTAUT model to examine technology adoption intention in different parts of the world (Zhou et al., 2010; Oliveira et al., 2014; Yuen et al., 2010; Yuen \& Yeow, 2009; Luo et al., 2010; Bhatiasevi, 2016). Bhatiasevi (2016) researched on the factors that influence mobile banking adoption by using the UTAUT model. His study extended the UTAUT model to include factors like perceived financial cost, perceived convenience and perceived credibility. Findings from his research confirm that in addition to UTAUT variables like effort expectancy, performance expectancy and social influence, perceived convenience and perceived credibility also explain consumers' behavioral intentions to use $\mathrm{m}$-banking. However, this work did not support the facilitating conditions hypothesis. Other scholars like Oliveira et al. (2014) combined UTAUT with TTF and ITM variables in order to establish their effect on behavioral intention. The combination established that initial trust, performance 
expectancy, technology characteristics, and task technology fit have significant effect on behavioral intention. We thus argue that UTAUT factors will influence the intention to adopt BBS Connect. We therefore make the following hypotheses:

H11: Performance expectancy positively affects user's intention to adopt BBS Connect.

H12: Effort expectancy positively affects the user's intention to adopt BBS Connect.

H13: Social influence positively affects user's intention to adopt BBS Connect.

H14: Facilitating conditions positively affect user's intention to adopt BBS Connect.

\section{Research Methodology}

\subsection{Sample and Data Collection}

For this research, a random sample of 120 responses was collected from BBS Connect system users. The users include account viewers, authorizers, checkers and makers from the Ugandan government ministries, departments, agencies and projects. The data was collected for a period of three months using online questionnaires in the English language. We used a convenience sampling method. The research approach is consistent with various technology adoption studies (Featherman \& Pavlou, 2003; Baganzi \& Lau, 2017). All the respondents were adequately educated, this is because educated people are more enthusiastic adopters of technology (Oliveira et al., 2016). A sample size of 100 is deemed to be sufficient and acceptable for empirical research (Anderson \& Gerbing, 1984; Luo et al., 2010). Luo et al. (2010: p. 227) used 122 responses for their empirical research. Structural Equation Modelling (SEM) measurement models can perform well with small samples of 50 - 100 responses (Afshan \& Sharif, 2016). Also, due to the weak Internet connectivity in Uganda (Baganzi \& Lau, 2017) and the low levels of Internet self-efficacy by customers, the sample was sufficient for performing estimations. We screened the sample data for missing values, and removed 10 responses due to incompleteness. This resulted in 110 valid responses for the present research whose descriptive statistics are as shown in Table 1.

\subsection{Measurement Development}

To test the hypothesized model shown in Figure 1, a survey instrument was prepared by adapting survey items from previous published empirical research. We used a five-point Likert scale from 1 (strongly disagree) to 5 (strongly agree) to design all the attributes for measuring each construct. The resulting questionnaire items used for the research survey are as shown in Table 2. We also collected the following respondents' demographic information; gender, age, monthly income, level of education, customer entity, user type, user experience, and user challenges. 
R. Baganzi et al.

Table 1. Descriptive statistics.

\begin{tabular}{|c|c|c|c|}
\hline Measure & Items & Frequency & Percentage \\
\hline \multirow{2}{*}{ Gender } & Female & 42 & 38.18 \\
\hline & Male & 68 & 61.82 \\
\hline \multirow{5}{*}{ Age } & $18-30$ & 7 & 6.36 \\
\hline & $31-40$ & 38 & 34.55 \\
\hline & $41-50$ & 51 & 46.36 \\
\hline & $51-60$ & 13 & 11.82 \\
\hline & 61 and above & 1 & 0.91 \\
\hline \multirow{5}{*}{ Monthly income } & Less than UGX $1 \mathrm{M}$ & 10 & 9.09 \\
\hline & UGX 1-5M & 57 & 51.82 \\
\hline & UGX 6-10M & 25 & 22.73 \\
\hline & UGX 11-20M & 15 & 13.64 \\
\hline & Over UGX 21M & 3 & 2.73 \\
\hline \multirow{3}{*}{ Level of Education } & Bachelor's degree & 40 & 36.36 \\
\hline & Master's degree & 62 & 56.36 \\
\hline & Ph.D & 8 & 7.27 \\
\hline \multirow{4}{*}{ Customer Entity } & Agency & 49 & 44.55 \\
\hline & Department & 5 & 4.55 \\
\hline & Ministry & 36 & 32.73 \\
\hline & Project & 20 & 18.18 \\
\hline \multirow{4}{*}{ User type } & Account Viewer & 7 & 6.36 \\
\hline & Authorizer & 29 & 26.36 \\
\hline & Checker & 14 & 12.73 \\
\hline & Maker & 60 & 54.55 \\
\hline \multirow{3}{*}{ User Experience } & Less than 1 year & 22 & 20.00 \\
\hline & $1-4$ years & 69 & 62.73 \\
\hline & $5-7$ years & 19 & 17.27 \\
\hline \multirow{4}{*}{ User Challenges } & Network challenges & 41 & 37.27 \\
\hline & Inadequate training & 23 & 20.91 \\
\hline & Limited usage time & 39 & 35.45 \\
\hline & System down time & 7 & 6.36 \\
\hline
\end{tabular}

Source: authors. 
Table 2. Questionnaire items.

\begin{tabular}{|c|c|c|c|}
\hline Constructs & Item & Survey Statement & Adapted from \\
\hline \multirow{3}{*}{$\begin{array}{l}\text { Familiarity with } \\
\text { BOU (FB) }\end{array}$} & FB1 & I am familiar with BOU through magazines, newspaper or TV. & \multirow{3}{*}{$\begin{array}{l}\text { (Afshan \& Sharif, 2016; } \\
\text { Gefen et al., 2003; Gu } \\
\quad \text { et al., 2009) }\end{array}$} \\
\hline & FB2 & $\begin{array}{l}\text { I am familiar with BOU through visiting its website and getting information } \\
\text { about it. }\end{array}$ & \\
\hline & FB3 & I am familiar with BOU through personal interactions. & \\
\hline \multirow{3}{*}{$\begin{array}{c}\text { Structural } \\
\text { Assurance (SA) }\end{array}$} & SA1 & $\begin{array}{l}\text { BBS Connect has enough safeguards that make me feel comfortable using it } \\
\text { to transact official business. }\end{array}$ & \multirow{3}{*}{ (McKnight et al., 2002) } \\
\hline & SA2 & $\begin{array}{l}\text { I feel assured of the legal and technological structure of BBS Connect to } \\
\text { protect me from financial losses. }\end{array}$ & \\
\hline & SA3 & $\begin{array}{l}\text { I feel confident that encryption and other technological advances of BBS } \\
\text { Connect make it safe for me to transact there. }\end{array}$ & \\
\hline \multirow{3}{*}{$\begin{array}{c}\text { Social } \\
\text { Influence (SI) }\end{array}$} & SI1 & My friends and workmates value the use of BBS Connect. & \multirow{3}{*}{$\begin{array}{l}\text { (Afshan \& Sharif, 2016; } \\
\text { Zhou et al., 2010; } \\
\text { Venkatesh et al., 2012) }\end{array}$} \\
\hline & SI 2 & The people that influence me use BBS Connect. & \\
\hline & SI3 & I find BBS Connect trendy. & \\
\hline \multirow{3}{*}{$\begin{array}{c}\text { Facilitating } \\
\text { Conditions (FC) }\end{array}$} & FC1 & I have all the necessary resources to use BBS Connect. & \multirow{3}{*}{$\begin{array}{l}\text { (Zhou et al., 2010; } \\
\text { Venkatesh et al., 2012) }\end{array}$} \\
\hline & FC2 & I have the knowledge necessary to use BBS Connect. & \\
\hline & FC3 & All the contents of BBS Connect services are easy to read and understand. & \\
\hline \multirow{3}{*}{$\begin{array}{l}\text { Task } \\
\text { Characteristics } \\
\text { (TAC) }\end{array}$} & $\mathrm{TAC} 1$ & I need to manage my accounts anytime anywhere. & \multirow{3}{*}{$\begin{array}{l}\text { (Afshan \& Sharif, 2016; } \\
\text { Zhou et al., 2010) }\end{array}$} \\
\hline & TAC2 & I need to do transfers anytime anywhere. & \\
\hline & TAC3 & I need to have a real time control in my accounts. & \\
\hline \multirow{3}{*}{$\begin{array}{l}\text { Technology } \\
\text { Characteristics } \\
\text { (TEC) }\end{array}$} & TEC1 & BBS Connect provides a quick service. & \multirow{3}{*}{$\begin{array}{l}\text { (Afshan \& Sharif, 2016; } \\
\text { Zhou et al., 2010) }\end{array}$} \\
\hline & TEC2 & BBS Connect provides a real time service. & \\
\hline & TEC3 & BBS Connect provides secure services. & \\
\hline \multirow{3}{*}{$\begin{array}{l}\text { Initial Trust } \\
\qquad(\mathrm{TR})\end{array}$} & TR1 & BBS Connect is a trustworthy service. & \multirow{3}{*}{$\begin{array}{l}\text { (Kim et al., 2009; } \\
\text { Chauhan, 2015) }\end{array}$} \\
\hline & TR2 & I can count on BBS Connect to protect my money. & \\
\hline & TR3 & I can count on BBS Connect to transfer my money safely. & \\
\hline \multirow{3}{*}{$\begin{array}{l}\text { Task Technology } \\
\text { Fit (TTF) }\end{array}$} & TTF1 & BBS Connect payment services are appropriate. & \multirow{3}{*}{$\begin{array}{l}\text { (Afshan \& Sharif, } \\
\text { 2016) }\end{array}$} \\
\hline & TTF2 & BBS Connect account management services are appropriate. & \\
\hline & TTF3 & Real time BBS Connect services are suitable. & \\
\hline \multirow{3}{*}{$\begin{array}{c}\text { Performance } \\
\text { Expectancy (PE) }\end{array}$} & PE1 & BBS Connect allows me to make my payments quicker. & \multirow{3}{*}{$\begin{array}{l}\text { (Afshan \& Sharif, 2016; } \\
\text { Zhou et al., 2010; } \\
\text { Venkatesh et al., 2012) }\end{array}$} \\
\hline & PE2 & I save time using BBS Connect. & \\
\hline & PE3 & BBS Connect optimizes my financial operations. & \\
\hline \multirow{3}{*}{$\begin{array}{l}\text { Effort Expectancy } \\
\text { (EE) }\end{array}$} & EE1 & It is easy to get to the BBS Connect web page. & \multirow{3}{*}{ (Venkatesh et al., 2012) } \\
\hline & EE2 & It is easy to login BBS Connect. & \\
\hline & EE3 & Learning to use BBS Connect is easy. & \\
\hline \multirow{3}{*}{$\begin{array}{l}\text { Behavioral } \\
\text { Intention (BI) }\end{array}$} & BI1 & I will certainly use BBS Connect to transact. & \multirow{3}{*}{$\begin{array}{l}\text { (Afshan \& Sharif, 2016; } \\
\text { Venkatesh et al., 2012; } \\
\text { Chauhan, 2015) }\end{array}$} \\
\hline & BI2 & $\begin{array}{l}\text { If I were asked about my opinion on BBS Connect, I would say something } \\
\text { favorable. }\end{array}$ & \\
\hline & $\mathrm{BI} 3$ & I want to know more about BBS Connect. & \\
\hline
\end{tabular}




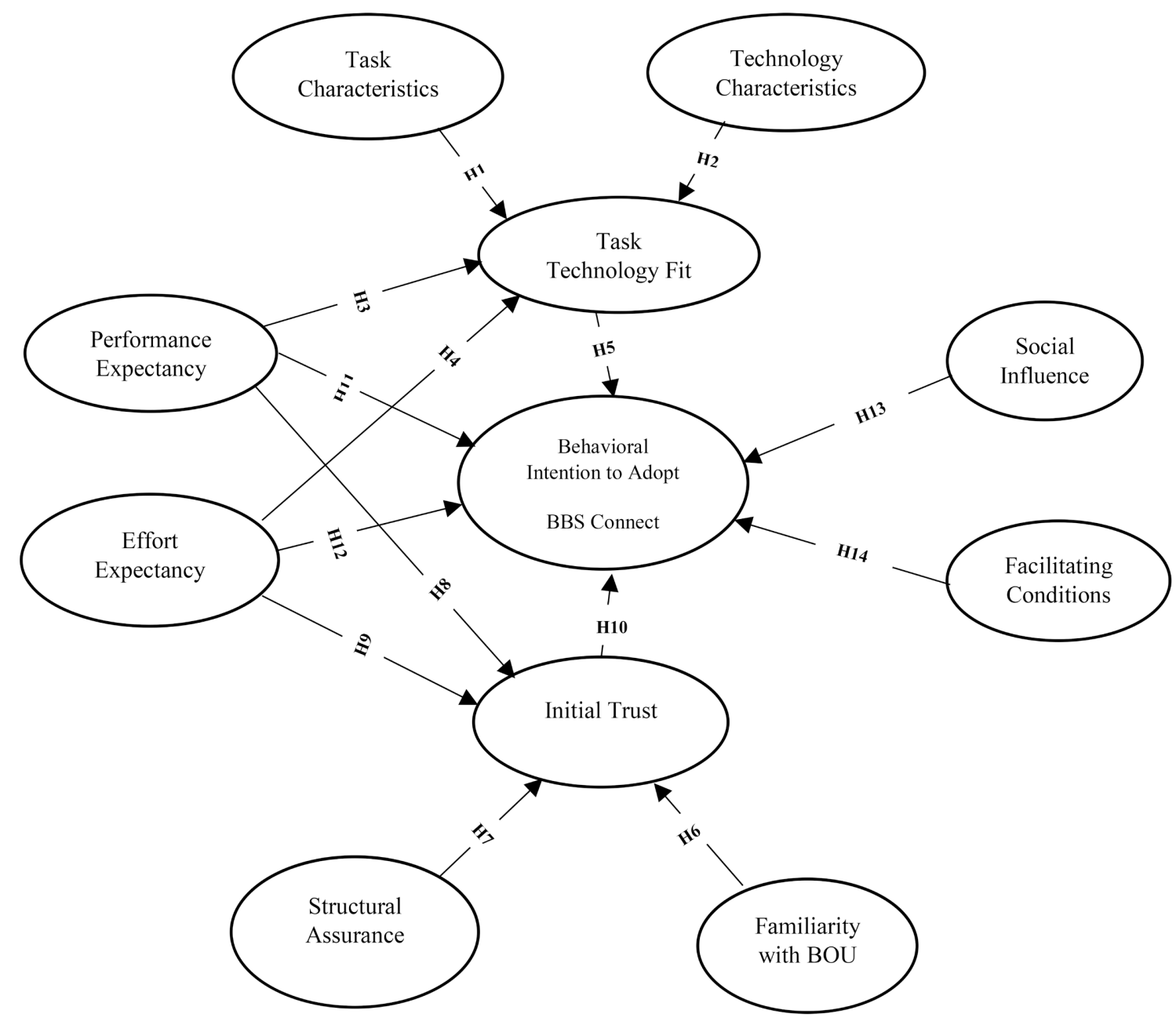

Figure 1. Conceptual BBS connect adoption intention model.

\subsection{Survey Results}

The 110 valid responses were further analyzed as follows. $62 \%$ were male and $38 \%$ were female; 7 were within 18 - 30 years old, 38 within 31 - 40 years old, 51 within 41 - 50 years, 13 within 51 - 60 years old, while 1 was over 61 years of age. Analysis of the level of education revealed that $36 \%$ had a bachelors' degree, $56 \%$ had a master's degree, and 7\% were at Ph.D level. Analysis of the level of monthly income showed that $9 \%$ earned less than UGX 1M (approximately less than \$270), 52\% earned UGX 1-5M (approximately \$270 - \$1351), 23\% earned UGX 6 - 10 M (approximately \$1621 - \$2702), 13\% earned UGX 11 - 20 M (approximately $\$ 2972$ - \$5404), and 3\% earned over UGX 21M (approximately over \$5674). Using a rate of 1 \$ equivalent to Uganda Shillings 3650. Analysis of the customer entity type revealed that $44 \%$ were from agencies, $5 \%$ from departments, $33 \%$ from ministries, and $18 \%$ from projects. Analysis of the user type revealed that $6 \%$ were account viewers, $26 \%$ were authorizers, $13 \%$ were checkers, and 55\% were makers. Assessment of user experience shows that $20 \%$ had a user experience of less than 1 year, $63 \%$ had a user experience of between $1-4$ 
years, and $17 \%$ had a user experience of 5 - 7 years. Further analysis of user challenges indicated that $37 \%$ experienced network challenges, $21 \%$ experienced inadequate training, and 35\% experienced limited usage time while $6 \%$ experienced system down time.

\section{Analysis of Results}

The data analysis was carried out using Smart PLS software for Structural Equation Modelling with sample size of $\mathrm{N}=110$. Partial Least Squares (PLS) places fewer restrictions on the sample size, measurement scales and residual distribution (Baganzi \& Lau, 2017; Chin \& Newsted, 1999). The method is highly recommended for testing hypotheses and developing new theory (Anderson \& Gerbing, 1988; Widayat et al., 2020). As recommended by Anderson and Gerbing (1988), we adopt an approach which involves a measurement model analysis followed by testing the structural relationships among the constructs.

\subsection{Measurement Model}

\subsubsection{Reliability}

The measurement model is assessed using reliability, which involves evaluating the indicator reliability and internal consistency reliability (Fang et al., 2014; Duane et al., 2014). Composite Reliability (CR) (Malaquias \& Hwang, 2016) can be used for testing internal consistency reliability. As shown in Table 3, the values in the third column exceed 0.7 as required (Widayat et al., 2020; Bagozzi \& $\mathrm{Yi}, 1988)$. Indicator reliability depends on whether their loadings exceed 0.7 (Gefen et al., 2000). As shown in Table 4, the magnitude of each indicator is 0.7 or more as required. Therefore, we can conclude that our measurements are reliable (Baganzi \& Lau, 2017; Widayat et al., 2020).

Table 3. Inter-Construct correlations and reliability.

\begin{tabular}{|c|c|c|c|c|c|c|c|c|c|c|c|c|c|}
\hline & $A V E$ & $C R$ & $B I$ & $E E$ & $F B$ & $F C$ & $P E$ & $S A$ & $S I$ & $T A C$ & $T E C$ & $T R$ & $T T F$ \\
\hline$B I$ & 0.6905 & 0.8677 & 0.8310 & & & & & & & & & & \\
\hline$E E$ & 0.7825 & 0.9151 & 0.5997 & 0.8846 & & & & & & & & & \\
\hline$F B$ & 0.5320 & 0.7718 & 0.3332 & 0.3600 & 0.7294 & & & & & & & & \\
\hline$F C$ & 0.6651 & 0.8563 & 0.5318 & 0.7252 & 0.3458 & 0.8155 & & & & & & & \\
\hline$P E$ & 0.8138 & 0.9291 & 0.8108 & 0.6467 & 0.2810 & 0.5155 & 0.9021 & & & & & & \\
\hline$S A$ & 0.7992 & 0.9227 & 0.6750 & 0.5029 & 0.3470 & 0.5348 & 0.6926 & 0.8940 & & & & & \\
\hline$S I$ & 0.6396 & 0.8409 & 0.6855 & 0.5427 & 0.3777 & 0.5282 & 0.6330 & 0.5460 & 0.7997 & & & & \\
\hline$T A C$ & 0.7265 & 0.8884 & 0.3394 & 0.4879 & 0.2999 & 0.4061 & 0.3576 & 0.2335 & 0.3611 & 0.8523 & & & \\
\hline$T E C$ & 0.6917 & 0.8704 & 0.6641 & 0.6548 & 0.3125 & 0.6575 & 0.6645 & 0.7295 & 0.6054 & 0.3668 & 0.8317 & & \\
\hline$T R$ & 0.8453 & 0.9424 & 0.7397 & 0.6841 & 0.3351 & 0.6524 & 0.7268 & 0.8388 & 0.6397 & 0.2493 & 0.7694 & 0.9194 & \\
\hline$T T F$ & 0.7637 & 0.9065 & 0.6963 & 0.6559 & 0.2987 & 0.6547 & 0.7544 & 0.6743 & 0.6761 & 0.3292 & 0.7668 & 0.7983 & 0.8739 \\
\hline
\end{tabular}

Notes: The diagonal shows the root square of the AVE of constructs. Sources: Smart-PLS output. 
Table 4. The matrix of Cross-Loadings and Loadings.

\begin{tabular}{|c|c|c|c|c|c|c|c|c|c|c|c|}
\hline & BI & EE & FB & FC & $P E$ & SA & SI & TAC & TEC & TR & TTF \\
\hline BI1 & 0.8978 & 0.6274 & 0.1699 & 0.5219 & 0.7930 & 0.6765 & 0.5455 & 0.3370 & 0.6334 & 0.7433 & 0.6408 \\
\hline BI2 & 0.9118 & 0.5594 & 0.3954 & 0.5418 & 0.7340 & 0.6333 & 0.6825 & 0.2907 & 0.6698 & 0.7201 & 0.7117 \\
\hline BI3 & 0.6587 & 0.2097 & 0.2906 & 0.1666 & 0.4247 & 0.2839 & 0.4758 & 0.1984 & 0.2538 & 0.2603 & 0.2917 \\
\hline EE1 & 0.5445 & 0.8896 & 0.3485 & 0.6027 & 0.5636 & 0.4553 & 0.4351 & 0.4516 & 0.6024 & 0.6290 & 0.5725 \\
\hline EE2 & 0.5193 & 0.9251 & 0.2451 & 0.6094 & 0.6012 & 0.4556 & 0.4757 & 0.4189 & 0.5484 & 0.6281 & 0.6080 \\
\hline EE3 & 0.5282 & 0.8369 & 0.3653 & 0.7180 & 0.5506 & 0.4229 & 0.5332 & 0.4244 & 0.5883 & 0.5558 & 0.5594 \\
\hline FB1 & 0.2320 & 0.1517 & 0.7190 & 0.2325 & 0.1989 & 0.2641 & 0.2912 & 0.1551 & 0.2908 & 0.2049 & 0.2311 \\
\hline FB2 & 0.2160 & 0.3880 & 0.8111 & 0.3120 & 0.2083 & 0.2329 & 0.2747 & 0.2843 & 0.2365 & 0.2946 & 0.2769 \\
\hline FB3 & 0.2958 & 0.2048 & 0.6489 & 0.1974 & 0.2114 & 0.2764 & 0.2691 & 0.1960 & 0.1640 & 0.2205 & 0.1324 \\
\hline FC1 & 0.4390 & 0.5847 & 0.2237 & 0.8210 & 0.4470 & 0.4669 & 0.5334 & 0.3174 & 0.5074 & 0.5823 & 0.5790 \\
\hline FC2 & 0.3250 & 0.6025 & 0.2713 & 0.8029 & 0.2862 & 0.2735 & 0.3239 & 0.4195 & 0.4425 & 0.3642 & 0.3305 \\
\hline FC3 & 0.5016 & 0.5928 & 0.3413 & 0.8227 & 0.4861 & 0.5165 & 0.4121 & 0.2875 & 0.6246 & 0.5993 & 0.6287 \\
\hline PE1 & 0.6557 & 0.5502 & 0.2447 & 0.4403 & 0.8949 & 0.5336 & 0.4728 & 0.3052 & 0.5686 & 0.6028 & 0.6893 \\
\hline PE2 & 0.8134 & 0.5969 & 0.2761 & 0.4465 & 0.9307 & 0.6425 & 0.5708 & 0.3046 & 0.5832 & 0.6580 & 0.6900 \\
\hline PE3 & 0.7175 & 0.6010 & 0.2384 & 0.5081 & 0.8800 & 0.6923 & 0.6636 & 0.3579 & 0.6458 & 0.7033 & 0.6633 \\
\hline SA1 & 0.6104 & 0.4652 & 0.2609 & 0.4567 & 0.5907 & 0.8688 & 0.3953 & 0.1448 & 0.7187 & 0.7352 & 0.5757 \\
\hline SA2 & 0.6080 & 0.4264 & 0.3425 & 0.5083 & 0.6128 & 0.9128 & 0.5174 & 0.2374 & 0.6550 & 0.7458 & 0.6169 \\
\hline $\mathrm{SA} 3$ & 0.5924 & 0.4572 & 0.3261 & 0.4691 & 0.6526 & 0.8998 & 0.5485 & 0.2422 & 0.5858 & 0.7677 & 0.6151 \\
\hline SI1 & 0.6711 & 0.4592 & 0.4100 & 0.4547 & 0.5817 & 0.6057 & 0.8443 & 0.2541 & 0.5607 & 0.6524 & 0.6336 \\
\hline SI2 & 0.3350 & 0.3278 & 0.2884 & 0.3434 & 0.3534 & 0.2215 & 0.7015 & 0.2601 & 0.2988 & 0.3332 & 0.3821 \\
\hline SI3 & 0.5557 & 0.4892 & 0.1951 & 0.4520 & 0.5323 & 0.3840 & 0.8450 & 0.3623 & 0.5276 & 0.4747 & 0.5511 \\
\hline TAC1 & 0.2329 & 0.3814 & 0.2411 & 0.2509 & 0.2251 & 0.0954 & 0.2587 & 0.8572 & 0.2385 & 0.1429 & 0.2301 \\
\hline TAC2 & 0.2481 & 0.3575 & 0.2360 & 0.2619 & 0.2395 & 0.1310 & 0.2420 & 0.8190 & 0.2530 & 0.1445 & 0.1907 \\
\hline TAC3 & 0.3509 & 0.4746 & 0.2790 & 0.4557 & 0.3940 & 0.3033 & 0.3780 & 0.8797 & 0.3956 & 0.2954 & 0.3639 \\
\hline TEC1 & 0.5688 & 0.5358 & 0.3015 & 0.5749 & 0.5138 & 0.5101 & 0.5060 & 0.2573 & 0.8502 & 0.5667 & 0.5822 \\
\hline TEC2 & 0.4722 & 0.5151 & 0.2288 & 0.5270 & 0.5339 & 0.4739 & 0.4904 & 0.3765 & 0.8659 & 0.5154 & 0.6751 \\
\hline TEC3 & 0.6192 & 0.5814 & 0.2540 & 0.5403 & 0.6052 & 0.8304 & 0.5131 & 0.2724 & 0.7762 & 0.8335 & 0.6463 \\
\hline TR1 & 0.7337 & 0.6390 & 0.2781 & 0.6102 & 0.7182 & 0.8231 & 0.5887 & 0.2600 & 0.7650 & 0.9461 & 0.7342 \\
\hline TR2 & 0.6939 & 0.6616 & 0.2691 & 0.6058 & 0.6907 & 0.8091 & 0.5906 & 0.2474 & 0.7507 & 0.9510 & 0.7320 \\
\hline TR3 & 0.6052 & 0.5841 & 0.3926 & 0.5856 & 0.5875 & 0.6709 & 0.5898 & 0.1730 & 0.5934 & 0.8582 & 0.7424 \\
\hline TTF1 & 0.5840 & 0.5487 & 0.2474 & 0.5583 & 0.6476 & 0.5015 & 0.5714 & 0.2806 & 0.6032 & 0.6368 & 0.8726 \\
\hline TTF2 & 0.6355 & 0.5632 & 0.2652 & 0.6188 & 0.6934 & 0.7130 & 0.6099 & 0.2046 & 0.7122 & 0.7794 & 0.8803 \\
\hline TTF3 & 0.6036 & 0.6074 & 0.2697 & 0.5364 & 0.6348 & 0.5427 & 0.5896 & 0.3820 & 0.6896 & 0.6697 & 0.8688 \\
\hline
\end{tabular}

Sources: Smart-PLS output. 


\subsubsection{Validity}

To examine the validity of reflective constructs, we use convergent and discriminant validity (Park et al., 2017). Convergent validity is assessed by evaluating the Average Variance Extracted (AVE) values (Park et al., 2017). As shown in the second column of Table 3, the AVEs of all constructs exceed the 0.5 acceptable threshold (Widayat et al., 2020; Fornell \& Larcker, 1981). The root square of the AVE of every construct is superior to the correlation between other constructs in the model and the construct (Chin \& Newsted, 1999). Therefore, the research model has appropriate convergent validity. Discriminant validity is represented by the inter indicators' patterns of a construct with other constructs (Duane et al., 2014). As shown in Table 4, the cross-factor loadings show that discriminant validity is appropriate, as the loading of each indicator on its assigned construct is more than its loading on other constructs (Baganzi \& Lau, 2017; Chin, 1998).

\subsection{Structural Model}

By running PLS algorithm, path coefficients and $\mathrm{R}^{2}$ values are obtained and used for assessing the predictive performance of the structural model (Park et al., 2017). PLS bootstrapping is used for prediction specification (Lu et al., 2017). Several researchers recommend the use of this approach for structural model analysis (Baganzi \& Lau, 2017; Fang et al., 2014). The structural model results are as shown in Figure 2. The bold lines show significant relationships while the insignificant ones are presented by the broken lines. $\mathrm{R}^{2}$ values are shown within the oval of each construct (Baganzi \& Lau, 2017). The model explains $70.4 \%$ of Task Technology Fit (TTF), 80\% of Initial Trust (TR) and 73.2\% of Behavioral Intentions (BI). We adopted a t-test to assess the directional hypotheses. The performed bootstrap was used for obtaining t-statistics for all hypotheses. The results of the hypothesis testing at $(p<0.05)$ are presented in Table 5.

Table 5. Summary of hypotheses testing results.

\begin{tabular}{ccccc}
\hline Hypotheses & Path & Path Coefficient $(\beta)$ & t Statistics & Conclusion \\
\hline H1 & TAC $\rightarrow$ TTF & -0.0362 & 0.6949 & Not supported \\
H2 & TEC $\rightarrow$ TTF & 0.4276 & 4.6431 & Supported \\
H3 & $\mathrm{PE} \rightarrow$ TTF & 0.3931 & 4.7050 & Supported \\
H4 & $\mathrm{EE} \rightarrow$ TTF & 0.1394 & 1.5949 & Not supported \\
H5 & TTF $\rightarrow$ BI & -0.0703 & 0.6357 & Not supported \\
H6 & FB $\rightarrow$ TR & -0.0212 & 0.4521 & Not supported \\
H7 & $\mathrm{SA} \rightarrow \mathrm{TR}$ & 0.6174 & 7.9535 & Supported \\
H8 & $\mathrm{PE} \rightarrow \mathrm{TR}$ & 0.1007 & 1.3529 & Not supported \\
$\mathrm{H} 9$ & $\mathrm{EE} \rightarrow \mathrm{TR}$ & 0.3161 & 2.4344 & Supported \\
$\mathrm{H} 10$ & $\mathrm{TR} \rightarrow \mathrm{BI}$ & 0.2607 & 4.7681 & Supported \\
$\mathrm{H} 11$ & $\mathrm{PE} \rightarrow \mathrm{BI}$ & 0.5272 & 0.1828 & Supported \\
$\mathrm{H} 12$ & $\mathrm{EE} \rightarrow \mathrm{BI}$ & -0.0176 & 2.7920 & Not supported \\
$\mathrm{H} 13$ & $\mathrm{SI} \rightarrow \mathrm{BI}$ & 0.2269 & 0.3239 & Supported \\
$\mathrm{H} 14$ & $\mathrm{FC} \rightarrow \mathrm{BI}$ & 0.0289 & & Not supported \\
\hline
\end{tabular}

Sources: Smart-PLS output. 


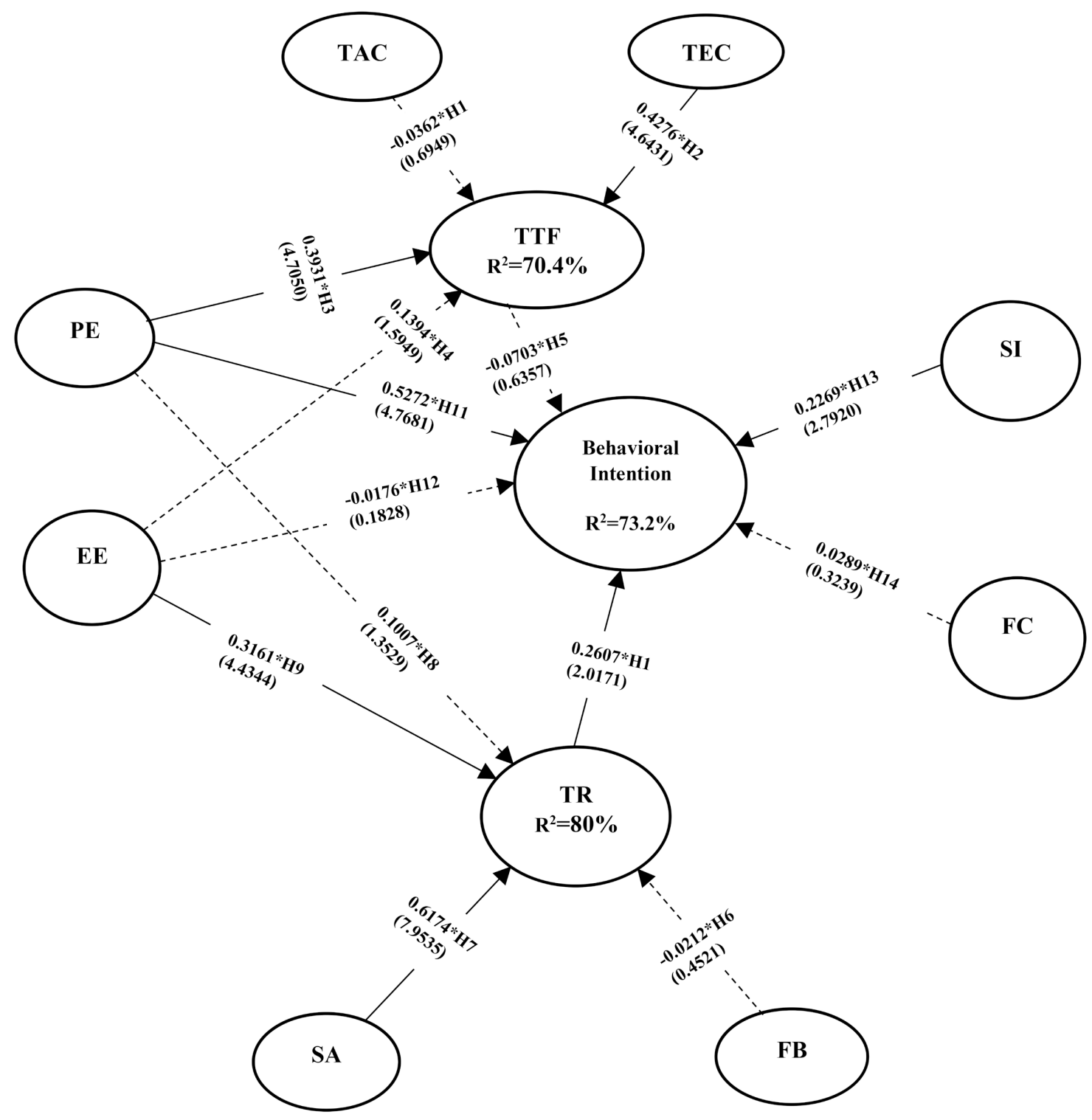

Figure 2. Structural model results. Sources: Smart-PLS output. Notes: Broken lines show path coefficients that are not significant. ${ }^{\star} P<0.05$.

\section{Discussion}

This study empirically investigated the factors that affect consumers' behavioral intention to adopt BBS Connect in Uganda. The research integrated three frameworks of TTF, UTAUT and ITM models in order to form a survey questionnaire. Based on these theories, we examined the role of environmental, behavioral and technological variables in predicting the intentions of BBS Connect users to adopt the Internet banking system used by the Bank of Uganda (BOU). The empirical findings are explained below.

\subsection{Task Technology Fit (TTF) Model}

The Internet banking system provided by the BBS Connect has been in opera- 
tion for a few years. Some BOU customers are not aware of the various banking tasks that can be executed using Internet banking. This explains the non-significant relationship between task characteristics (TAC) and task technology fit (TTF) as shown in H1 $(\beta=-0.0362, t=0.6949)$. There exists a significant relationship between technology characteristics (TEC) and task technology fit (TTF) as shown in $\mathrm{H} 2(\beta=0.4276, \mathrm{t}=4.6431)$. This implies that the customers appreciate the immediacy, security and ubiquity of BBS Connect. We found a significant relationship between performance expectancy (PE) and task technology fit (TTF) as shown in $\mathrm{H} 3(\beta=0.3931, \mathrm{t}=4.7050)$. This implies that BBS Connect is capable of ensuring job optimization of its users. Effort expectancy (EE) did not significantly influence task technology fit (TTF) as shown in $\mathrm{H} 4(\beta=0.1394, \mathrm{t}=$ 1.5949). This implies that the ease of use of BBS Connect does not affect its capability in ensuring job optimization. Task technology fit (TTF) did not significantly influence behavioral intention to adopt BBS Connect as shown by $\mathrm{H} 5$ ( $\beta=$ $-0.0703, t=0.6357)$. This implies that even though BBS Connect is useful in ensuring job optimization, it may not necessarily mean that BOU customers want to use it to transact, as they have other alternative platforms like IFMS and mobile money. However, Internet banking is growing in recognition as a useful banking service in Uganda and the model explains $70.4 \%$ of the variation in TTF.

\subsection{Initial Trust Model (ITM)}

Based on the ITM model, one of the predictors of initial trust was found to significantly surge initial trust while the other did not. Familiarity with BOU (FB) H6 ( $\beta=-0.0212, t=0.4521)$ did not significantly influence initial trust of BBS Connect, while structural assurance (SA) H7 ( $\beta=0.6174, t=7.9535)$ significantly influenced initial trust of BBS Connect. This implies that to the Internet banking users, it doesn't matter what they know about BOU, the more familiar they are with the system, the less trust they have. However, the technological and legal structures of Internet Banking play a key role in building customers' trust. It shows the relevance of policies regarding confidentiality, service guarantees, endorsement and third party acknowledgement in BBS Connect (Afshan \& Sharif, 2016; McKnight et al., 2004). Performance expectancy (PE) H8 ( $\beta=0.1007, \mathrm{t}$ $=1.3529$ ) did not significantly influence initial trust of BBS Connect. This implies that much as the Internet banking system can support job performance, it does not imply that customers trust the online medium for transacting. Effort expectancy (EE) H9 ( $\beta=0.3161, t=4.4344)$ significantly influenced initial trust of BBS Connect. This implies that the Internet banking system is easy to use and customers can rely on it. Initial trust (TR) H10 ( $\beta=0.2607, t=2.0171)$ significantly influenced behavioral intention to BBS Connect. This implies that the Internet banking system is reliable and customers are willing to use it. This is consistent with other scholars like Afshan and Sharif (2016); Oliveira et al. (2014); Kim et al. (2009). 


\subsection{Unified Theory of Acceptance and Use of Technology (UTAUT)}

Based on the UTAUT model, the study findings indicate the dominating contribution of performance expectancy $(\mathrm{PE}) \mathrm{H} 11(\beta=0.5272, \mathrm{t}=4.7681)$ in influencing behavioral intention to BBS Connect. The Banks should therefore focus on providing convenience avenues to their customers with easy to use Internet Banking interfaces. This is followed by a positive and significant contribution of social influence (SI) H13 ( $\beta=0.2269, \mathrm{t}=2.7920)$ in influencing behavioral intention to BBS Connect. This implies that what Internet banking users say to their peers may influence their behaviour towards the system. However, effort expectancy (EE) H12 $(\beta=-0.0176, t=0.1828)$ did not significantly influence behavioral intention to adopt BBS Connect. This implies that some customers may not see BBS Connect as an easy to use system. Similar results were shown by facilitating conditions (FC) H14 ( $\beta=0.0289, \mathrm{t}=0.3239)$ which did not significantly influence behavioral intention to BBS Connect. This finding is consistent with another scholar, Bhatiasevi (2016).

\section{Theoretical and Practical Implications}

The findings from this study contribute to the awareness of the factors that affect Internet banking adoption intentions in under developed countries. The study provides a framework that combines three well established technology acceptance theories. Most Internet banking studies focus on the user perceptions of technology and ignore the impact of task technology fit. Similar to other scholars, for instance, Oliveira et al. (2014) and Afshan \& Sharif (2016), this study bridges the gap by combining environmental variables of familiarity and structural assurance, task and technological features, and the user perception aspect. Therefore, investigating Internet banking acceptance requires not only focusing on perceptions, but also considering the fit of task and technology.

There are few empirical studies on Internet banking acceptance in Uganda which creates a gap in understanding the major issues affecting user acceptance of BBS Connect. Therefore, it was necessary to have a clear perspective of the critical facets of Internet Banking acceptance and active participation of BBS Connect users. This has revealed the importance of environmental and technological aspects in solving Internet banking issues in Uganda. The findings are important in designing technology awareness programs and proper marketing strategies for Internet banking by central banks, and commercial banks. This will help in developing plans at country level to minimize the uncertainty associated with Internet banking transactions with unbiased technological and legal structures. This will be relevant in building Ugandan users' trust in Internet banking services.

The TTF model used in this study considers the technological aspects of Internet banking that influence user performance. As Internet banking is in its early growth stages, it is necessary and important to initiate effective marketing campaigns to promote Internet banking use. This awareness can influence con- 
sumers' decision to adopt Internet banking. The customers must be informed of the benefits of Internet banking and banks must ensure that their Internet banking services provide rapid access, widespread accessibility, and minimal risk and enhance customer Internet banking experiences.

Findings from the study reveal that initial trust significantly influences behavioral intentions to BBS Connect, while effort expectancy significantly influences initial trust. One of the major hindrances to Internet banking acceptance is the privacy and safety concerns. Banks need to take trust as a serious factor and ensure that they gain customer trust in order to have a sustainable competitive advantage. Therefore, banks may stimulate initial trust in Internet banking by communicating their customer protection policies and guarantees during marketing campaigns.

Findings from effort expectancy imply that the system is not user friendly for customers to use. Therefore, there is need for more training related activities to ensure users are well versed with the system. This can be done using virtual and video trainings.

The study reveals the significant contribution of social influence in influencing behavioral intention of BBS Connect. Banks need to ensure satisfied customers because customer word of mouth has a significant impact in influencing new customers to accept Internet banking services. Serious marketing strategies and campaigns geared towards winning customers towards Internet banking are therefore necessary.

\section{Limitations and Future Research}

Like every research, our study encountered some limitations. Firstly, the study is limited by a small sample size. There is a tendency for customers to shy away from online surveys, and this is worsened by the weak Internet connectivity to complete online surveys, in addition to cost elements. We propose future field surveys to collect responses from users on a face to face basis. Secondly, the study focused on BBS Connect users, who do not represent the entire Ugandan banking population. We recommend future studies to focus on Internet banking systems provided by commercial banks. This will help to capture all customers' responses in the Ugandan banking sector. The study was conducted in Uganda, where Internet banking is still in its early stages. The findings may not be generalizable to countries with developed Internet banking systems. We recommend the application of similar models in other countries like China, Korea, Japan and South Africa. This would help to see the variability of the model across different countries.

\section{Conclusion}

This research provides a comprehensive model with various factors affecting Internet banking acceptance. The model combines constructs from Unified Theory of Acceptance and Use of Technology, Initial Trust Model and Task Technology 
Fit. Findings indicate that the hypothesized models integrate fairly and half of the hypotheses are significant. Analysis of statistical results reveals that task characteristics do not significantly contribute to task technology fit while technology characteristics do. Initial trust was found to be facilitated by structural assurance and not by familiarity with BOU. The empirical findings support the association of initial trust, performance expectancy and social influence with intention to adopt BBS Connect. The comprehensive model provides insights into the Internet banking literature that can help banks to focus on the key aspects that are relevant for the development of the Internet banking industry. Research findings will enable banks enhance Internet banking growth and provide management with new insights for designing the right marketing strategies intended toward Internet banking acceptance.

\section{Authors' Contributions}

Conceptualization, R.B., B.M.; Literature review, R.B., B.M., R.I.K; Methodology and analysis, R.B., B.M.; Writing, review and editing, R.B., B.M., R.I.K.

\section{Acknowledgements}

We thank the anonymous reviewers for their comments. We acknowledge the support from the Central Bank of Uganda, Banking Department, and the Internet Banking Section. We also acknowledge the support from all BBS Connect users in Government Ministries, Departments, Agencies and Projects who participated in the survey.

\section{Disclaimer}

The views expressed in this article are those of the authors and not necessarily the institutions affiliated with the study. The usual caveats apply.

\section{Conflicts of Interest}

The authors declare no conflicts of interest regarding the publication of this paper.

\section{References}

Afshan, S., \& Sharif, A. (2016). Acceptance of Mobile Banking Framework in Pakistan. Telematics and Informatics, 33, 370-387. https://doi.org/10.1016/j.tele.2015.09.005

Ajzen, I. (1991). The Theory of Planned Behaviour. Journal of Organizational Behaviour and Human Decision Processes, 50, 179-211. https://doi.org/10.1016/0749-5978(91)90020-T

Al-Gahtani, S. S., Hubona, G. S., \& Wang, J. (2007). Information Technology (IT) in Saudi Arabia: Culture and the Acceptance and Use of IT. Information and Management, 44, 681-691. https://doi.org/10.1016/j.im.2007.09.002

Anderson, J. C., \& Gerbing, D. W. (1984). The Effect of Sampling Error on Convergence, Improper Solutions, and Goodness-of-Fit Indices for Maximum Likelihood Confirma- 
tory Factor Analysis. Psychometrika, 49, 155-173.

https://doi.org/10.1007/BF02294170

Anderson, J. C., \& Gerbing, D. W. (1988). Structural Equation Modelling in Practice: A Review and Recommended Two-Step Approach. Psychological Bulletin, 103, 411-423. https://doi.org/10.1037/0033-2909.103.3.411

Baganzi, R., \& Lau, A. K. W. (2017). Examining Trust and Risk in Mobile Money Acceptance in Uganda. Sustainability, 9, Article No. 2233.

https://doi.org/10.3390/su9122233

Baganzi, R., Shin, G.-C., \& Wu, S. (2019). Examining Consumers' Attitudes toward Gmarket Online Shopping. J, 2, 364-383. https://doi.org/10.3390/j2030025

Bagozzi, R. P., \& Yi, Y.-J. (1988). On the Evaluation of Structural Equation Models. Journal of the Academy of Marketing Science, 16, 74-94.

https://doi.org/10.1007/BF02723327

Bank of Uganda (2019). Annual Report 2019. Bank of Uganda. https://www.bou.or.ug/bou/bouwebsite/bouwebsitecontent/publications/Annual Repo rts/All/Annual-Report-2019.pdf

Bank of Uganda (2020). Annual Report 2020. Bank of Uganda. https://www.bou.or.ug/bou/bouwebsite/bouwebsitecontent/publications/Annual Repo rts/All/Annual-Report-2019-2020.pdf

Bank of Uganda. (2017). Banking \& Currency, Banking Application. Bank of Uganda. https://www.bou.or.ug/bou/bouwebsite/BankingandCurrency/bankigapplication.html

Bank of Uganda. (2018). Internet Banking Facility (BBS-Connect System) at Bank of Uganda. Bank of Uganda.

https://www.bou.or.ug/bou/bouwebsite/BankingandCurrency/BBSConnect.html

Bhatiasevi, V. (2016). An Extended UTAUT Model to Explain the Adoption of Mobile Banking. Information Development, 32, 799-814.

https://doi.org/10.1177/0266666915570764

Chauhan, S. (2015). Acceptance of Mobile Money by Poor Citizens of India: Integrating Trust into the Technology Acceptance Model. Info, 17, 58-68.

https://doi.org/10.1108/info-02-2015-0018

Chin, W. W. (1998). The Partial Least Squares Approach for Structural Equation Modeling. In G. A. Marcoulides (Ed.), Modern Methods for Business Research (pp. 295-336). Lawrence Erlbaum Associates.

Chin, W. W., \& Newsted, P. R. (1999). Structural Equation Modeling Analysis with Small Samples Using Partial Least Squares. In R. H. Hoyle (Ed.), Statistical Strategies for Small Sample Research (pp. 307-341). SAGE Publications.

Davis, F. D. (1989). Perceived Usefulness, Perceived Ease of Use, and User Acceptance of Information Technology. MIS Quarterly, 13, 319-340. https://doi.org/10.2307/249008

Duane, A., O’Reilly, P., \& Andreev, P. (2014). Realising M-Payments: Modelling Consumers' Willingness to M-Pay Using Smartphones. Behaviour \& Information Technology, 33, 318-334. https://doi.org/10.1080/0144929X.2012.745608

Fang, Y., Qureshi, I., Sun, H., McCole, P., Ramsey, E., \& Lim, K. H. (2014). Trust, Satisfaction, and Online Repurchase Intention: The Moderating Role of Perceived Effectiveness of E-Commerce Institutional Mechanisms. MIS Quarterly, 38, 407-427.

https://doi.org/10.25300/MISQ/2014/38.2.04

Featherman, M. S., \& Pavlou, P. A. (2003). Predicting E-Services Adoption: A Perceived Risk Facets Perspective. International Journal of Human Computer Studies, 59, 451-474. 
https://doi.org/10.1016/S1071-5819(03)00111-3

Fishbein, M., \& Ajzen, I. (1975). Belief, Attitude, Intention and Behavior: An Introduction to Theory and Research. Addison-Wesley.

Fornell, C., \& Larcker, D. F. (1981). Evaluating Structural Equation Models with Unobservable Variables and Measurement Error. Journal of Marketing, 18, 39-50. https://doi.org/10.1177/002224378101800104

Gefen, D. (2000). E-Commerce: The Role of Familiarity and Trust. Omega, 28, 725-737. https://doi.org/10.1016/S0305-0483(00)00021-9

Gefen, D., Karahanna, E., \& Straub, D. W. (2003). Trust and TAM in Online Shopping: An Integrated Model. MIS Quarterly, 27, 51-90. https://doi.org/10.2307/30036519

Gefen, D., Straub, D. W., \& Boudreau, M.-C. (2000). Structural Equation Modeling and Regression: Guidelines for Research and Practice. Communications of the Association for Information Systems, 4, 1-77. https://doi.org/10.17705/1CAIS.00407

Goodhue, D. L. (1995). Understanding User Evaluations of Information Systems. Management Science, 41, 1827-1844. https://doi.org/10.1287/mnsc.41.12.1827

Goodhue, D. L., \& Thompson, R. L. (1995). Task-Technology Fit and Individual Performance. MIS Quarterly, 19, 213-236. https://doi.org/10.2307/249689

Gu, J.-C., Lee, S.-C., \& Suh, Y.-H. (2009). Determinants of Behavioral Intention to Mobile Banking. Expert Systems with Applications, 36, 11605-11616. https://doi.org/10.1016/j.eswa.2009.03.024

Harrison, D. A., Mykytyn Jr., P. P., \& Riemenschneider, C. K. (1997). Executive Decisions About Adoption of Information Technology in Small Business: Theory and Empirical Tests. Information Systems Research, 8, 171-195. https://doi.org/10.1287/isre.8.2.171

Jagero, N., \& Abeka, S. O. (2011). Corporate Customers Usage of Internet Banking in East Africa. International Journal of Computer Science Issues, 8, 394-402.

Junglas, I., Abraham, C., \& Watson, R. T. (2008). Task-Technology Fit for Mobile Locatable Information Systems. Decision Support Systems, 45, 1046-1057.

https://doi.org/10.1016/j.dss.2008.02.007

Kim, G.-M., Shin, B.-S., \& Lee, H.-G. (2009). Understanding Dynamics between Initial Trust and Usage Intentions of Mobile Banking. Information Systems Journal, 19, $283-$ 311. https://doi.org/10.1111/j.1365-2575.2007.00269.x

Kim, K.-K., \& Prabhakar, B. (2004). Initial Trust and the Adoption of B2C E-Commerce. ACM SIGMIS Database, 35, 50-64. https://doi.org/10.1145/1007965.1007970

Kumar, A., Dhingra, S., Batra, V., \& Purohit, H. (2020). A Framework of Mobile Banking Adoption in India. Journal of Open Innovation: Technology, Market, and Complexity, 6, Article No. 40. https://doi.org/10.3390/joitmc6020040

Lowry, P. B., Vance, A., Moody, G., Beckman, B., \& Read, A. (2008). Explaining and Predicting the Impact of Branding Alliances and Web Site Quality on Initial Consumer Trust of E-Commerce Web Sites. Journal of Management Information Systems, 24, 199-224. https://doi.org/10.2753/MIS0742-1222240408

Lu, J., Wei, J., Yu, C.-S., \& Liu, C. (2017). How Do Post-Usage Factors and Espoused Cultural Values Impact Mobile Payment Continuation? Behaviour \& Information Technology, 36, 140-164. https://doi.org/10.1080/0144929X.2016.1208773

Luo, X., Li, H., Zhang, J., \& Shim, J. P. (2010). Examining Multi-Dimensional Trust and Multi-Faceted Risk in Initial Acceptance of Emerging Technologies: An Empirical Study of Mobile Banking Services. Decision Support Systems, 49, 222-234.

https://doi.org/10.1016/j.dss.2010.02.008 
Malaquias, R. F., \& Hwang, Y.-J. (2016). An Empirical Study on Trust in Mobile Banking: A Developing Country Perspective. Computers in Human Behavior, 54, 453-461. https://doi.org/10.1016/j.chb.2015.08.039

Martins, C., Oliveira, T., \& Popovič, A. (2014). Understanding the Internet Banking Adoption: A Unified Theory of Acceptance and Use of Technology and Perceived Risk Application. International Journal of Information Management, 34, 1-13. https://doi.org/10.1016/j.ijinfomgt.2013.06.002

McKnight, D. H., \& Chervany, N. L. (2001). What Trust Means in E-Commerce Customer Relationships: An Interdisciplinary Conceptual Typology. International Journal of Electronic, 6, 35-59. https://doi.org/10.1080/10864415.2001.11044235

McKnight, D. H., Choudhury, V., \& Kacmar, C. (2002). Developing and Validating Trust Measures for E-Commerce: An Integrative Typology. Information Systems Research, 13, 334-359. https://doi.org/10.1287/isre.13.3.334.81

McKnight, D. H., Kacmar, C. J., \& Choudhury, V. (2004). Dispositional Trust and Distrust Distinctions in Predicting High- and Low-Risk Internet Expert Advice Site Perceptions. E-Service Journal, 3, 35-58. https://doi.org/10.2979/esj.2004.3.2.35

Min, Q., Ji, S., \& Qu, G. (2008). Mobile Commerce User Acceptance Study in China-A Revised UTAUT Model. Tsinghua Science and Technology, 13, 257-264. https://doi.org/10.1016/S1007-0214(08)70042-7

Musiime, A., \& Malinga, R. (2011). Internet Banking, Consumer Adoption and Customer Satisfaction. African Journal of Marketing Management, 3, 261-269.

https://academicjournals.org/article/article1379684738 Musiime\%20and\%20Ramadha $\underline{\text { n.pdf }}$

Mwesigwa, A. (2016, August 17). By Ensuring Financial Stability, Bank of Uganda Is Protecting Taxpayers' Money. Observer.

https://observer.ug/business/38-business/45950-by-ensuring-financial-stability-bank-of -uganda-is-protecting-taxpayers-money

Oliveira, T., Faria, M., Thomas, M. A., \& Popovič, A. (2014). Extending the Understanding of Mobile Banking Adoption: When UTAUT Meets TTF and ITM. International Journal of Information Management, 34, 689-703. https://doi.org/10.1016/j.ijinfomgt.2014.06.004

Oliveira, T., Thomas, M., Baptista, G., \& Campos, F. (2016). Mobile Payment: Understanding the Determinants of Customer Adoption and Intention to Recommend the Technology. Computers in Human Behavior, 61, 404-414. https://doi.org/10.1016/j.chb.2016.03.030

Park, J.-Y., Sung, C.-S., \& Im, I. (2017). Does Social Media Use Influence Entrepreneurial Opportunity? A Review of Its Moderating Role. Sustainability, 9, Article No. 1593. https://doi.org/10.3390/su9091593

Rogers, E. M. (1983). The Diffusion of Innovations. Free Press.

Roy, S. K., Balaji, M. S., Kesharwani, A., \& Sekhon, H. (2017). Predicting Internet Banking Adoption in India: A Perceived Risk Perspective. Journal of Strategic Marketing, 25, 418-438. https://doi.org/10.1080/0965254X.2016.1148771

Venkatesh, V., Morris, M. G., Davis, G. B., \& Davis, F. D. (2003). User Acceptance of Information Technology: Toward a Unified View. MIS Quarterly, 27, 425-478. https://doi.org/10.2307/30036540

Venkatesh, V., Thong, J., \& Xu, X. (2012). Consumer Acceptance and Use of Information Technology: Extending the Unified Theory of Acceptance and Use of Technology. MIS Quarterly, 36, 157-178. https://doi.org/10.2307/41410412 
Widayat, W., Masudin, I., \& Satiti, R. (2020). E-Money Payment: Customers' Adopting Factors and the Implication for Open Innovation. Journal of Open Innovation: Technology, Market, and Complexity, 6, Article No. 57.

https://doi.org/10.3390/joitmc6030057

Williams, M. D., Dwivedi, Y. K., Lal, B., \& Schwarz, A. (2009). Contemporary Trends and Issues in IT Adoption and Diffusion Research. Journal of Information Technology, 24, 1-10. https://doi.org/10.1057/jit.2008.30

Yadav, R., Chauhan, V., \& Pathak, G. S. (2015). Intention to Adopt Internet Banking in an Emerging Economy: A Perspective of Indian Youth. International Journal of Bank Marketing, 33, 530-544. https://doi.org/10.1108/IJBM-06-2014-0075

Yiga, C., \& Cha, K.-J. (2016). Toward Understanding the Importance of Trust in Influencing Internet Banking Adoption in Uganda. Information Development, 32, 622-636. https://doi.org/10.1177/0266666914563359

Yu, P. L., Balaji, M. S., \& Khong, K. W. (2015). Building Trust in Internet Banking: A Trustworthiness Perspective. Industrial Management \& Data Systems, 115, 235-252. https://doi.org/10.1108/IMDS-09-2014-0262

Yuen, Y. Y., \& Yeow, P. H. P. (2009). User Acceptance of Internet Banking Service in Malaysia. In J. Cordeiro, S. Hammoudi, \& J. Filipe (Eds.), Web Information Systems and Technologies (pp.295-306). Springer. https://doi.org/10.1007/978-3-642-01344-7 22

Yuen, Y. Y., Yeow, P. H. P., Lim, N., \& Saylani, N. (2010). Internet Banking Adoption: Comparing Developed and Developing Countries. Journal of Computer Information Systems, 51, 52-61.

Zhou, T., Lu, Y., \& Wang, B. (2010). Integrating TTF and UTAUT to Explain Mobile Banking User Adoption. Computers in Human Behavior, 26, 760-767.

https://doi.org/10.1016/j.chb.2010.01.013 